\title{
Recent Advances in treatment of urethral stricture disease in
}

\section{men [version 1; peer review: 2 approved]}

\author{
Naside Mangir (D), Christopher Chapple
}

Department of Functional and Reconstructive Urology, Royal Hallamshire Hospital, Glossop Road, Sheffield, S10 2JF, UK

V1 First published: 05 May 2020, 9(F1000 Faculty Rev):330

https://doi.org/10.12688/f1000research.21957.1

Latest published: 05 May 2020, 9(F1000 Faculty Rev):330

https://doi.org/10.12688/f1000research.21957.1

\section{Abstract}

Urethral stricturing is a narrowing of the urethral lumen as a result of ischaemic spongiofibrosis. The main challenge of currently available treatment options is recurrence of the stricture. Recent advancements in the treatment of urethral strictures mainly came from the fields of regenerative medicine and tissue engineering. Research efforts have primarily focused on decreasing the recurrence of stricture after internal urethrotomy and constructing tissue-engineered urethral substitutes to improve clinical outcomes of urethroplasty surgeries. The aim of this article is to review the most recent advancements in the management of urethral stricture disease in men.

\section{Keywords}

urethral stricture, urethroplasty, urethral reconstruction, regenerative medicine, tissue engineering

\section{Open Peer Review}

Approval Status

1

2

\section{version 1}

05 May 2020

Faculty Reviews are review articles written by the prestigious Members of Faculty Opinions. The articles are commissioned and peer reviewed before publication to ensure that the final, published version is comprehensive and accessible. The reviewers who approved the final version are listed with their names and affiliations.

1. Sanjay B. Kulkarni, Kulkarni Reconstructive Urology Center, Pune, India

Pankaj Joshi ID, Kulkarni Reconstructive

Urology Center, Pune, India

2. Boyd R Viers, Mayo Clinic, Rochester, USA

Any comments on the article can be found at the end of the article. 
Corresponding author: Christopher Chapple (c.r.chapple@sheffield.ac.uk)

Author roles: Mangir N: Data Curation, Formal Analysis, Writing - Original Draft Preparation, Writing - Review \& Editing; Chapple C: Conceptualization, Funding Acquisition, Investigation, Project Administration, Supervision, Writing - Original Draft Preparation, Writing Review \& Editing

Competing interests: Christopher R. Chapple declares that he is a consultant for Astellas, Bayer, Contura, Ferring, Pierre Fabre, Symimetic, and Urovant Sciences; an author for Allergan, Astellas, and Ferring; an investigator for Astellas and Bayer; a co-patent holder for Symimetic; and a speaker for Astellas and Lupin. Naside Mangir declares that she has no competing interests.

Grant information: The author(s) declared that no grants were involved in supporting this work.

Copyright: (c) 2020 Mangir N and Chapple C. This is an open access article distributed under the terms of the Creative Commons Attribution License, which permits unrestricted use, distribution, and reproduction in any medium, provided the original work is properly cited.

How to cite this article: Mangir $\mathrm{N}$ and Chapple $\mathrm{C}$. Recent Advances in treatment of urethral stricture disease in men [version 1; peer review: 2 approved] F1000Research 2020, 9(F1000 Faculty Rev):330 https://doi.org/10.12688/f1000research.21957.1

First published: 05 May 2020, 9(F1000 Faculty Rev):330 https://doi.org/10.12688/f1000research.21957.1 


\section{Introduction}

Urethral stricturing is a narrowing of the urethral lumen as a result of ischaemic spongiofibrosis ${ }^{1}$. Several aetiologic factors have been proposed, including trauma due to urethral instrumentation, infection, and inflammatory disorders such as balanitis xerotica obliterans. These create the initial epithelial injury, which then heals by fibrosis, resulting in a reduction in the urethral caliber and impairment to the flow of urine. Urethral strictures (US) can have significant adverse effects on physical and psychosocial well-being ${ }^{2}$.

The approach to US disease is mainly driven by the anatomical location of the stricture, whether it is in the anterior or posterior urethra, and its relationship to the distal urethral sphincter mechanism. Posterior US often result from direct trauma or surgical interventions, such as transurethral prostate resection or radical prostatectomy, and can be treated effectively with dilatation if they are a stenosis of the sphincetric area. Disruption injuries of the urethra, although causing a stenosis, are not true strictures as defined above because there is discontinuity of the urethra, for example following a pelvic fracture or in the bulbar urethra following a fall astride injury, which is an indication for excision primary anastomosis (EPA) of the damaged segment with anastomosis of the two healthy urethral ends. Short strictures affecting the proximal portion of the anterior urethra can also be treated by dilatation, endoscopic incision, or EPA, with success rates in excess of $90 \%$ in many series ${ }^{3,4}$. Longer strictures or strictures affecting more distal portions of the anterior urethra require substitution urethroplasty using tissue flaps or grafts. A variety of tissue grafts such as from the bladder ${ }^{5}$ and colonic mucosa ${ }^{6}$ have been used. Currently, there appears to be increasing support for the use of buccal mucosa grafts for substitution urethroplasty ${ }^{1}$, which, based on current knowledge, should be considered to be the most appropriate material.

Direct vision internal urethrotomy (DVIU) is the first-line treatment for US in men; however, stricture recurrence is still a problem, with a stricture-free rate of around $20 \%$ in long-term follow-up 7 . Current guidelines recommend that patients with longer ( $>2 \mathrm{~cm}$ in length), multiple, penile, or distal strictures and extensive periurethral spongiofibrosis should not be offered repeated DVIUs, as they have a very limited chance of a durable cure. The same applies to shorter strictures that have failed to respond to one urethrotomy or if the stricture recurs within 3 months of the first incision ${ }^{8}$. Such patients should be offered a urethroplasty, which has success rates of up to $95 \%^{3}$, with anastomotic repairs typically being more successful compared to augmented repairs, where success rates of $80-85 \%$ are commonly reported ${ }^{4}$.

New advances in the treatment of US in males have mainly come from the fields of regenerative medicine and tissue engineering. This research has primarily focused on decreasing the recurrence of US after DVIU using regenerative therapies and constructing tissue-engineered urethral substitutes to improve clinical outcomes of urethroplasty surgeries. The aim of this article is to review the most recent advances in the management of US disease in men.

\section{Regenerative therapies to improve the outcomes of DVIU}

The pathophysiologic processes leading to the formation of a US are still not completely elucidated. An initial epithelial injury followed by an abnormal wound healing process that leads to the formation of a progressive fibrotic scar is probably complex and multifactorial at a cellular and molecular level ${ }^{9}$. DVIU works by cutting a scar through the diseased area and allowing the healthy spongy tissue to regenerate through secondary healing.

Fibrotic tissue formation is the final common pathway for many fibrotic diseases. Following on from this, intralesional injection of antifibrotic agents/drugs (e.g. mitomycin C, corticosteroids, etc.) after DVIU has been studied in the past ${ }^{10}$. A summary of the current strategies underlying the current advances in the treatment of US disease is presented in Table 1. To date, there is limited evidence from small clinical trials to show that such an approach is effective in preventing the recurrence of US after DVIU.

A recent development in this area is the commercialisation of a drug-coated balloon catheter (Optilume ${ }^{\mathrm{TM}}$ ), which combines a balloon dilation technique and drug delivery. The highly lipophilic drug, paclitaxel, is released after balloon dilatation, limiting hyperactive cell proliferation and fibrotic scar formation ${ }^{11}$. Paclitaxel is an antineoplastic drug that inhibits cell replication by stabilising intracellular microtubules. Paclitaxel is thought to inhibit the proliferation of ureteral smooth muscle cells and urothelial cells. The distribution of paclitaxel in the urothelial, submucosal, and smooth muscle layers has previously been demonstrated in a porcine model after ureteral dilatation, showing reduced inflammation with drug-eluting balloons $^{12}$. The pseudostratified epithelium of the urethral mucosa has also been shown to permit the distribution of paclitaxel in the muscular layer in a rabbit model ${ }^{13}$. Nevertheless, there is no direct evidence to suggest an effect of paclitaxel on US. This technology is now undergoing clinical trials. The interim results of the first non-randomised clinical trial with 53 patients showed that such an approach could be used safely in the treatment of short bulbar US with an anatomical success rate of $70 \%$ at 12 months $^{14}$. The efficacy and safety will need to be studied in long-term randomised controlled clinical trials.

\section{Cell-based regenerative therapies}

In addition to drug treatments, recently, cellular and noncellular regenerative medicine products have been tried. A recent randomised controlled clinical trial investigated the submucosal injection of platelet-rich plasma (PRP) after DVIU and showed a reduction in the recurrence of stricture in patients with primary, short, bulbar strictures where stricture recurrence was confirmed by postoperative urethrography ${ }^{15}$. PRP is a concentrated suspension of platelets that is obtained easily by centrifugation of whole blood with a separator to remove other cellular components. It has been shown to have a high concentration of biologically active proteins such as transforming growth factor (TGF)- $\beta$, platelet-derived growth factor, and vascular endothelial growth factor, which can promote angiogenesis, wound healing, and deposition of matrix proteins. The 
Table 1. A summary of novel technologies in the treatment of urethral stricture disease.

\begin{tabular}{|c|c|c|}
\hline & Proposed mechanism of action & Comment \\
\hline \multicolumn{3}{|l|}{$\begin{array}{l}\text { Strategies to improve the } \\
\text { outcomes of endoscopic } \\
\text { interventions }\end{array}$} \\
\hline $\begin{array}{l}\text { Intralesional injection of } \\
\text { antifibrotic agents/drugs } \\
\text { after direct vision internal } \\
\text { urethrotomy (DVIU) }\end{array}$ & $\begin{array}{l}\text { Tissue regeneration in the corpus spongiosum } \\
\text { improved after the fibrotic scar is cut }\end{array}$ & $\begin{array}{l}\text { Small clinical trials showed limited efficacy in } \\
\text { preventing recurrence of stricture }\end{array}$ \\
\hline $\begin{array}{l}\text { Balloon dilatation of the stricture } \\
\text { using drug-coated balloon } \\
\text { catheters }\end{array}$ & $\begin{array}{l}\text { Drugs released during balloon dilatation limit } \\
\text { hyperactive cell proliferation and fibrotic scar } \\
\text { formation at the urethral scar site }\end{array}$ & $\begin{array}{l}\text { Short-term follow-up demonstrated safe use } \\
\text { with good efficacy } \\
\text { Long-term results from randomised controlled } \\
\text { trials are required }\end{array}$ \\
\hline $\begin{array}{l}\text { Submucosal injection of cell- } \\
\text { based regenerative therapy } \\
\text { products after DVIU }\end{array}$ & $\begin{array}{l}\text { Uses the anti-fibrotic and regenerative properties } \\
\text { of platelet-rich plasma and mesenchymal stem } \\
\text { cells }\end{array}$ & $\begin{array}{l}\text { No major safety concerns with autologous } \\
\text { cells; however, their efficacy is debatable } \\
\text { mainly owing to the variability in the quality and } \\
\text { quantity of cell therapy products }\end{array}$ \\
\hline \multicolumn{3}{|l|}{$\begin{array}{l}\text { Tissue engineering strategies } \\
\text { to replace damaged urethra }\end{array}$} \\
\hline $\begin{array}{l}\text { Epithelial cell-seeded graft } \\
\text { implantation }\end{array}$ & $\begin{array}{l}\text { Mature cells, generally from buccal mucosa, are } \\
\text { combined with injectable scaffolds that cells can } \\
\text { attach to and proliferate from after endoscopically } \\
\text { injected to the site of urethral damage }\end{array}$ & $\begin{array}{l}\text { The main advantage comes from the } \\
\text { concentration of therapy products at the site of } \\
\text { injection } \\
\text { Can be considered an endoscopic means of } \\
\text { urethral reconstruction; however, not yet tested } \\
\text { in clinical trials }\end{array}$ \\
\hline $\begin{array}{l}\text { Construction of tissue } \\
\text { engineered urethral tissue for } \\
\text { urethral reconstruction }\end{array}$ & $\begin{array}{l}\text { This represents the state-of-the-art construction } \\
\text { of artificial urethral tissue from cells isolated from } \\
\text { biopsy samples and scaffolds from natural or } \\
\text { artificial sources }\end{array}$ & $\begin{array}{l}\text { Studied extensively in clinical trials with } \\
\text { promising results } \\
\text { The regulatory approval processes that need } \\
\text { to be followed and the costs of such therapies } \\
\text { can be a potential limitation when widespread } \\
\text { clinical use is desired }\end{array}$ \\
\hline
\end{tabular}

regenerative properties of PRP have been supported by in vitro and in vivo studies, and PRP injection is becoming increasingly popular for clinical application in the treatment of burns, wound healing problems, and orthopaedic soft tissue injuries ${ }^{16,17}$. Although autologous PRP would not be expected to be associated with any safety concerns, its efficacy is still debatable. In our view, this approach remains investigational, as there appears to be a significant lack of standardisation in terminology, content, and quality of the PRP used in clinical trials ${ }^{18}$.

There have also been studies investigating the efficacy of mesenchymal stem cells (MSCs) in the treatment of US in men. MSCs are known to have a rich secretome that has a positive influence on tissue regeneration ${ }^{19}$. In the context of US disease, adipose-derived MSCs have been shown to decrease collagen I and III deposition ${ }^{20}$ and result in less-extensive urethral fibrotic changes in imaging and histology in rat models ${ }^{21}$. In this model, a stricture was created by injection of TGF- $\beta 1$ into the rat urethra; TGF- $\beta$ is the main regulator of tissue fibrosis in many biological processes ${ }^{22}$. In another study, TNF- $\alpha-$ induced exosomal miR-146a, an anti-inflammatory miRNA expressed in the MSC exosome, was shown to mediate the antifibrotic action of MSCs, counteracting stricture formation ${ }^{23}$. Hence, there is some evidence from animal studies suggesting MSC injection could be beneficial as an adjunct to DVIU, but adequate clinical studies have yet to be performed.
MSCs have also been suggested as an adjuvant cellular therapy after substitution urethroplasty. In this context, bone marrow-derived MSCs have been shown to modulate the immune response with a significant reduction in pro-inflammatory cytokines TNF- $\alpha$ and IL-1 $\beta$, a shift in collagen type from III to I, and wound healing in a rat model of substitution urethroplasty where a synthetic graft seeded with MSCs was used $^{24}$.

The main problems with the clinical application of stem cells in this context are related to the in vivo fate of the injected stem cells. Although MSCs are known to migrate to sites of tissue injury even after IV injection, to date there is no clinical evidence to suggest whether these cells engraft successfully after transurethral injection, how long they survive, and whether they can migrate to other body parts. Additionally, the best source of MSCs (autologous versus allogeneic and fat versus bone marrow) and the optimum number of cells needed to achieve a desired effect are not yet known ${ }^{19}$.

\section{Tissue engineering-based regenerative therapies}

The overall strategy of tissue engineering approaches is to combine a scaffold made of synthetic or natural biomaterials with cells isolated from patients whilst incorporating bioactive factors into these constructs to trigger the desired physiological response. Constructing complex tissues and solid organs is 
an inherently difficult task, primarily because vascularisation cannot be created and functioning innervation cannot be replicated. Nevertheless, several pilot clinical studies have been conducted showing clinically beneficial outcomes with the use of tissue-engineered oral mucosa ${ }^{19}$.

Recently, a pilot clinical study investigated another novel tissue engineering approach in six $\operatorname{men}^{25}$. Epithelial cells isolated from patients' own oral mucosa were encapsulated in a thermoresponsive polymer, which was then injected into the urethra after DVIU. The cell-polymer mixture was also shown to organise into a composite cell-scaffold complex to support the growth of the epithelial cells. Compared to cell-based adjuvant therapies after DVIU, tissue engineering approaches could be advantageous because cell-scaffold complexes can result in the concentration of therapeutic products at the injection site. However, these products require a specialised regulatory pathway before being introduced into mainstream clinical practice.

Recently, tissue-engineered products have been used as an adjunct to DVIU. In a pre-clinical study in rabbits, minced buccal mucosa suspended in fibrin gel, liquid buccal mucosa graft (LBMG), was applied to the site of urethrotomy after DVIU $^{26}$. The LBMG was shown to effectively graft onto the wound site in $67 \%$ of animals, with an improved rate of stricture resolution in the treatment group. This is a proof-of-concept study, and this approach has not been tested in clinical practice.

More extensive reconstruction of the urethra using tissueengineered urethral substitutes has been ongoing over the past 10 years. The recent pre-clinical and clinical studies investigating a tissue-engineered product for urethroplasty have been summarised in detail elsewhere ${ }^{27}$. The first use of tissueengineered oral mucosa for urethral reconstruction was performed by our group in $2008^{28}$. In this study, five patients with lengthy strictures due to lichen sclerosis received a tissueengineered urethral substitute implantation that was constructed using patients' own oral mucosa cells. In long-term follow-up, four out of five patients still had their tissue-engineered urethras in place, which looked normal on endoscopic examination ${ }^{29}$. The first nationally authorised tissue-engineered product, currently legally marketed in Germany, consists of autologous oral mucosa cells seeded on a degradable scaffold. At twoyear follow-up, the failure rate with this product was $40 \% \%^{30}$, with significant variation in success rates between centres involved in the clinical trial. Larger prospective clinical trials with long-term follow-up using standardised outcome assessment measures are needed.

To summarise, tissue engineering offers exciting developments in the management of US disease. There appears to be some progress in constructing a safe and reliable tissueengineered graft for urethroplasty; however, a better understanding of the mechanisms and risk factors for graft failure with different graft materials and designs is needed. Recent developments in the regulatory processes that need to be followed with the introduction of a tissue engineering approach are discussed in the next section. A further caveat is that such therapies are likely to be associated with high costs as compared to existing surgery using autologous tissue, such as oral mucosa, when introduced into more widespread clinical use.

\section{Recent changes in the regulatory processes}

Advances in biomedical science and technologies over the past few decades have made it more difficult for regulatory bodies to ensure safe processes governing the production, distribution, and approval of advanced therapy medicinal products (ATMPs). Until recently, new treatments coming into clinical practice were regulated under either novel drug treatments or medical devices. These failed to address the complexity and diversity of the newly emerging regenerative medicine products such as cell therapies, tissue engineering, and gene therapies. Here we will briefly summarise the recent changes made to these regulatory processes.

In the EU, new regulations governing the safe use of medical devices entered into force recently ${ }^{31}$. The regulatory definition of regenerative medicine involves "methods to replace or regenerate human cells, tissues, or organs in order to restore or establish normal function which includes cell therapies, tissue engineering, gene therapy, and biomedical engineering techniques as well as more traditional treatments involving pharmaceuticals, biologics, and devices". On the other hand, the definition of a tissue-engineered product is much more complicated because of the diversity of its components, which is now subject to regulations under specific legislations ${ }^{32}$.

Another specific term used by the authorities is ATMP, which refers to a tissue-engineered product that "contains or consists of engineered cells or tissues, and which is presented as having properties for, or is used in, or administered to, human beings with a view to regenerating, repairing, or replacing human tissue $^{33}$ ". An 'engineered cell' is defined as "a cell that has been subject to substantial manipulation (such as cutting, grinding, shaping, centrifugation or soaking in antibiotic or antimicrobial solutions) so that biological characteristics, physiological functions or structural properties relevant for the intended regeneration, repair or replacement are achieved". Additionally, a cell is classified as an engineered cell when it is "not intended to be used for the same essential function or functions in the recipient as in the donor", for example when an adipose tissue cell is used to regenerate muscle tissue.

Therefore, the above-described tissue-engineered injectable products designed as adjuncts to DVIU and the tissueengineered urethral substitutes would need to be considered as ATMPs. The regulatory evaluation of ATMPs often requires very specific expertise covering the areas of biotechnology and medical devices. The cellular injectables could also be considered ATMPs depending on the cellular elements involved and how much they have been manipulated.

\section{Conclusions}

Innovative research is being undertaken to achieve better clinical results in the treatment of US disease. The development 
of tissue-engineered urethral substitutes has received a lot of attention over the past decade. Although this is still ongoing, current research appears to focus on improving the success of DVIU using regenerative medicine and tissue-engineered products. This is a newly developing area, and currently there is a lack of robust evidence for clinical efficacy alongside a lack of standardisation for definitions and unclear regulatory pathways for commercialisation.
1. F Latini JM, McAninch JW, Brandes SB, et al.: SIU/ICUD Consultation On Urethral Strictures: Epidemiology, Etiology, Anatomy, and Nomenclature of Urethral Stenoses, Strictures, and Pelvic Fracture Urethral Disruption Injuries. Urology. 2014; 83(3 Suppl): S1-7.

PubMed Abstract | Publisher Full Text | F1000 Recommendation

2. Whybrow P, Rapley T, Pickard R, et al.: How Men Manage Bulbar Urethra Stricture by Concealing Urinary Symptoms. Qual Health Res. 2015; 25(10): 1435-42.

PubMed Abstract | Publisher Full Text

3. Santucci RA, Mario LA, McAninch JW: Anastomotic Urethroplasty for Bulbar Urethral Stricture: Analysis of 168 Patients. J Urol. 2002; 167(4): 1715-9. PubMed Abstract | Publisher Full Text

4. Barbagli G, Guazzoni G, Lazzeri M: One-stage Bulbar Urethroplasty: Retrospective Analysis of the Results in 375 Patients. Eur Urol. 2008; 53(4): 828-33.

PubMed Abstract | Publisher Full Text

5. Kinkead TM, Borzi PA, Duffy PG, et al.: Long-term Followup of Bladder Mucosa Graft for Male Urethral Reconstruction. J Urol. 1994; 151(4): 1056-8. PubMed Abstract | Publisher Full Text

6. $\mathrm{F}$ Xu YM, Qiao Y, Sa YL, et al.: Urethral reconstruction using colonic mucosa graft for complex strictures. J Urol. 2009; 182(3): 1040-3. PubMed Abstract | Publisher Full Text | F1000 Recommendation

7. Steenkamp JW, Heyns CF, de Kock ML: Internal Urethrotomy Versus Dilation as Treatment for Male Urethral Strictures: A Prospective, Randomized Comparison. J Urol. 1997; 157(1): 98-101. PubMed Abstract | Publisher Full Text

8. Chapple C, Andrich D, Atala A, et al:: SIU/ICUD Consultation on Urethral Strictures: The Management of Anterior Urethral Stricture Disease Using Substitution Urethroplasty. Urology. 2014; 83(3 Suppl): S31-47. PubMed Abstract | Publisher Full Text

9. F El Agha E, Kramann R, Schneider RK, et al:: Mesenchymal Stem Cells in Fibrotic Disease. Cell Stem Cell. 2017; 21(2): 166-77. PubMed Abstract | Publisher Full Text | F1000 Recommendation

10. Park JJ, Kuo TL, Chapple CR: Mitomycin C in the Treatment of Anterior Urethral Strictures. Nat Rev Urol. 2018; 15(12): 717-8.

PubMed Abstract | Publisher Full Text

11. Elliott S, Virasoro R, DeLong J, et al.: PD22-06 one-year safety and efficacy outcomes on a novel drug coated balloon (DCB) for urethral stricture disease the ROBUST I study. J Urol. 2019; 201(Supplement 4). Publisher Full Text

12. Liourdi D, Kallidonis $\mathrm{P}$, Kyriazis I, et al.: Evaluation of the distribution of Paclitaxel by immunohistochemistry and nuclear magnetic resonance spectroscopy after the application of a drug-eluting balloon in the porcine ureter. J Endourol. 2015; 29(5): 580-9. PubMed Abstract | Publisher Full Tex

13. F Barbalias D, Lappas G, Ravazoula P, et al.: Evaluation of the Distribution of Paclitaxel After Application of a Paclitaxel-Coated Balloon in the Rabbit Urethra. J Endourol. 2018; 32(5): 381-6.

PubMed Abstract | Publisher Full Text | F1000 Recommendation

14. F Virasoro R, DeLong JM, Mann RA, et al:: A drug-coated balloon treatment for urethral stricture disease: Interim results from the ROBUST I study. Can Urol Assoc J. 2020; 14(6) PubMed Abstract | Publisher Full Text | F1000 Recommendation

15. F Rezaei M, Badiei R, Badiei R: The effect of platelet-rich plasma injection on post-internal urethrotomy stricture recurrence. World J Urol. 2019; 37(9): 1959-64

PubMed Abstract | Publisher Full Text | F1000 Recommendation

16. Dombrowski ME, Yasui $Y$, Murawski $C D$, et al.: Conservative Management and Biological Treatment Strategies: Proceedings of the International Consensus Meeting on Cartilage Repair of the Ankle. Foot Ankle Int. 2018; 39(1_suppl): 9S-15S.

PubMed Abstract | Publisher Full Text
17. Lavery LA, Davis KE, Berriman SJ, et al.: WHS guidelines update: Diabetic foot ulcer treatment guidelines. Wound Repair Regen. 2016; 24(1): 112-26. PubMed Abstract | Publisher Full Text

18. Harrison P; Subcommittee on Platelet Physiology.: The use of platelets in regenerative medicine and proposal for a new classification system: guidance from the SSC of the ISTH. J Thromb Haemost. 2018; 16(9): 1895-900. PubMed Abstract | Publisher Full Text

19. F Mangır N, Türkeri L: Stem cell therapies in post-prostatectomy erectile dysfunction: a critical review. Can J Urol. 2017; 24(1): 8609-19. PubMed Abstract | F1000 Recommendation

20. Sangkum P, Yafi FA, Kim H, et al.: Effect of adipose tissue-derived stem cel injection in a rat model of urethral fibrosis. Can Urol Assoc J. 2016; 10(5-6): E175-E180.

PubMed Abstract | Publisher Full Text | Free Full Text

21. F Castiglione F, Dewulf K, Hakim L, et al:: Adipose-derived Stem Cells Counteract Urethral Stricture Formation in Rats. Eur Urol. 2016; 70(6): 1032-41. PubMed Abstract | Publisher Full Text | F1000 Recommendation

22. Meng XM, Nikolic-Paterson DJ, Lan HY: TGF- $\beta$ : The Master Regulator of Fibrosis. Nat Rev Nephrol. 2016; 12(6): 325-38. PubMed Abstract | Publisher Full Text

23. Liang YC, Wu Y-P, Li XD, et al.: TNF- $\alpha$-induced Exosomal miR-146a Mediates Mesenchymal Stem Cell-Dependent Suppression of Urethral Stricture. J Cell Physiol. 2019; 234(12): 23243-55.

PubMed Abstract | Publisher Full Text

24. Liu JS, Bury MI, Fuller NJ, et al.: Bone Marrow Stem/Progenitor Cells Attenuate the Inflammatory Milieu Following Substitution Urethroplasty. Sci Rep. 2016; 6 : 35638.

PubMed Abstract | Publisher Full Text | Free Full Text

25. F Vaddi SP, Reddy VB, Abraham SJK: Buccal Epithelium Expanded and Encapsulated in Scaffold-Hybrid Approach to Urethral Stricture (BEES-HAUS) Procedure: A Novel Cell Therapy-Based Pilot Study. Int J Urol. 2019; 26(2): 253-7.

PubMed Abstract | Publisher Full Text | F1000 Recommendation

26. F Scott KA, Li G, Manwaring J, et al.: Liquid Buccal Mucosa Graft Endoscopic Urethroplasty: A Validation Animal Study. World J Urol. 2019. PubMed Abstract | Publisher Full Text | F1000 Recommendation

27. Mangir N, Wilson KJ, Osman NI, et al:: Current State of Urethral Tissue Engineering. Curr Opin Urol. 2019; 29(4): 385-93. PubMed Abstract | Publisher Full Text

28. Bhargava S, Patterson JM, Inman RD, et al.: Tissue-engineered Buccal Mucosa Urethroplasty-Clinical Outcomes. Eur Urol. 2008; 53(6): 1263-9. PubMed Abstract | Publisher Full Text

29. Osman NI, Patterson JM, MacNeil S, et al: Long-term Follow-Up After TissueEngineered Buccal Mucosa Urethroplasty. Eur Urol. 2014; 66(4): 790-1. PubMed Abstract | Publisher Full Text

30. F Ram-Liebig G, Barbagli G, Heidenreich A, et al:: Results of Use of TissueEngineered Autologous Oral Mucosa Graft for Urethral Reconstruction: A Multicenter, Prospective, Observational Trial. EBioMedicine. 2017; 23: 185-92. PubMed Abstract | Publisher Full Text | Free Full Text | F1000 Recommendation

31. Internal Market, Industry, Entrepreneurship and SMEs. European Commission: [Accessed: 06-Feb-2019]. Reference Source

32. European Medicines Agency: Multi-stakeholder advanced therapy medicinal products (ATMPs) expert meeting: exploring solutions to foster ATMPs' development and patient access in Europe. 2016. [Accessed: 21-Feb-2019]. Reference Source

33. REGULATION (EC) No 1394/2007 OF THE EUROPEAN PARLIAMENT AND OF THE COUNCIL of 13 November 2007 on advanced therapy medicinal products and amending Directive 2001/83/EC and Regulation (EC) No 726/2004 (Text with EEA relevance). Official Journal of the European Union. 2007.

Reference Source 


\section{Open Peer Review}

\section{Current Peer Review Status:}

\section{Editorial Note on the Review Process}

Faculty Reviews are review articles written by the prestigious Members of Faculty Opinions. The articles are commissioned and peer reviewed before publication to ensure that the final, published version is comprehensive and accessible. The reviewers who approved the final version are listed with their names and affiliations.

\section{The reviewers who approved this article are:}

\section{Version 1}

\section{Boyd R Viers}

Department of Urology, Mayo Clinic, Rochester, MN, USA

Competing Interests: No competing interests were disclosed.

2. Sanjay B. Kulkarni

Kulkarni Reconstructive Urology Center, Pune, Maharashtra, India

Pankaj Joshi (D)

Kulkarni Reconstructive Urology Center, Pune, Maharashtra, India

Competing Interests: No competing interests were disclosed.

The benefits of publishing with F1000Research:

- Your article is published within days, with no editorial bias

- You can publish traditional articles, null/negative results, case reports, data notes and more

- The peer review process is transparent and collaborative

- Your article is indexed in PubMed after passing peer review

- Dedicated customer support at every stage

For pre-submission enquiries, contact research@f1000.com 